\title{
Penentuan Sistem Pengadaan Bahan Baku Utama Berbasis Kontrak pada Perusahaan Roti dan Kue-Kue ANDALAS
}

\author{
${ }^{1}$ Irma Felicia, ${ }^{2}$ Carles Sitompul, ${ }^{3}$ Paulina Kus Ariningsih \\ 1,2,3) Fakultas Teknologi Industri, Jurusan Teknik Industri, Universitas Katolik Parahyangan \\ Jl. Ciumbuleuit 94, Bandung 40141 \\ Email:6116100@student.unpar.ac.id, carles@unpar.ac.id, paulina.ariningsih@unpar.ac.id
}

\begin{abstract}
Micro, small and medium enterprises (MSME) are striving to maximize profits through cost's reduction while maintaining their product qualities and their customer's satisfaction. ANDALAS is an MSME producing cakes and breads that intuitively purchase its raw material which results in a relatively high purchase cost. We propose a contract-based system using a linear programming approach to manage the purchasing activities of main ingredients. A mathematical model is proposed supporting the purchasing decisions which includes constraints such as: minimum purchase, safety stock, warehouse capacity, and demand's requirements. The resulting model provides an improvement of 6,30\% reduction in purchase costs. The improvement for each ingredient ranges from $4 \%$ to $16 \%$ where Eggs, Flour, Maizena, Margarine, Butter and Sugar are contractually ordered from one main supplier.
\end{abstract}

Keywords: supply contracts, purchasing, optimization, linear programming

\begin{abstract}
Abstrak
Usaha Mikro, Kecil, dan Menengah (UMKM) berusaha untuk memaksimasi profit dengan cara mengurangi ongkos, namun harus tetap mempertahankan kualitas produk dan kepuasan pelanggan. ANDALAS adalah sebuah UMKM yang memproduksi kue-kue dan roti yang melakukan pembelian bahan bakunya secara intuitif. Hal ini menyebabkan ongkos pembelian menjadi lebih mahal. Oleh karena itu, penelitian ini mengusulkan sebuah sistem pembelian yang berbasis kontrak dengan menggunakan metode program linear dalam proses pembelian bahan-bahan baku utama. Sebuah model matematis dirancang untuk mendukung keputusan pembelian dengan berbagai pembatas seperti: minimum pembelian, persediaan pengaman, kapasitas penyimpanan, dan kebutuhan permintaan. Model ini memberikan hasil berupa pengurangan ongkos total pembelian sebanyak 6,3\%. Dari bahan baku yang diteliti yaitu Telur, Tepung, Maizena, Margarin, Mentega dan Telur, pengurangan ongkos berkisar di antara $4 \%-16 \%$ jika bahan-bahan ini dipesan pada satu pemasok utama.
\end{abstract}

Kata kunci: kontrak pasokan, pengadaan bahan baku, optimasi, pemrograman linear

\section{Pendahuluan}

Persaingan dalam dunia industri semakin ketat dengan tingginya standar kualitas konsumen dan biaya produksi terutama untuk Usaha Mikro, Kecil, dan Menengah (UMKM) di Indonesia. UMKM memiliki tujuan yang sama seperti industri lainnya yaitu memperoleh keuntungan maksimal dengan tetap memperhatikan kepuasan pelanggan. Menurut Simchi-Levi et al. (2008) keuntungan dapat dimaksimalkan dengan memperhatikan keseimbangan antara pendapatan dan pengeluaran. Target keuntungan dapat dimaksimalkan dengan perhitungan biaya yang tepat.

Persediaan dan sumber daya memiliki peran besar dalam suatu rantai pasok dikarenakan adanya ketidaksesuaian penawaran dan permintaan. Hal ini berkaitan dengan pemilihan sumber daya dalam proses pengadaan bahan baku. Berbagai pilihan pengadaan bahan baku dapat dipertimbangkan untuk kemungkinan 
yang paling menguntungkan (Chopra \& Meindl, 2010).

Perencanaan bahan baku dilakukan dengan berkoordinasi dengan pemasok terkait dengan kualitas, pengiriman, jumlah, dan lain sebagainya (Sitompul, 2019). Pengendalian bahan baku dilakukan untuk memastikan bahan baku dapat memenuhi permintaan konsumen dalam periode waktu tertentu. Oleh karena itu, suatu usaha memerlukan strategi pembelian yang efektif dengan memperhatikan risiko persediaan dan harga (Martinez-de-Albeniz \& Simchi-Levi, 2009). Perencanaan bahan baku yang tepat dapat mencegah pemborosan bahan baku serta penundaan produksi dikarenakan pembelian bahan baku berlebih atau berkekurangan.

Pembelian bahan baku dapat dilakukan dengan negosiasi dengan pemasok sesuai dengan kebutuhan perusahaan terkait dengan jumlah, jenis barang, harga, pengiriman, dan lain sebagainya. Kesepakatan dapat dilakukan dengan referensi negosiasi dan termin pembelian yang dicantumkan dalam kontrak. Termin kontrak berisikan hak dan kewajiban yang harus dipenuhi oleh pembeli dan penjual selama periode kontrak berlangsung.

Perusahaan roti dan kue-kue ANDALAS merupakan salah satu UMKM yang bergerak dalam bidang makanan di kota Malang. Perusahaan ini memproduksi berbagai macam jenis roti, kue kering, dan kue basah dengan sistem produksi make to order dan made to stock. Perusahaan roti dan kue-kue ANDALAS melakukan pembelian bahan baku seperti tepung terigu, telur, mentega, gula, vanili, dan lain-lain setiap awal bulan pada pemasok $X$.

Pembelian bahan baku dilakukan secara intuitif oleh pemilik perusahaan dengan kekurangan bahan baku dibeli secara tentatif pada pemasok $X$ atau pada pemasok lain jika pemasok $X$ tidak dapat memenuhi kekurangan tersebut. Ketidakpastian jumlah dan harga dari tiap pemesanan menyebabkan tidak adanya perhitungan pengadaan bahan baku yang stabil. Menurut keterangan pemilik usaha, ketidakpastian jumlah dan harga pemesanan bahan baku menyebabkan target keuntungan yang diinginkan belum tentu tercapai. Oleh karena itu, perusahaan roti dan kue-kue ANDALAS memerlukan sistem pengadaan bahan baku berbasis kontrak untuk meminimasi total biaya bahan baku.

\section{Metode Penelitian}

Penelitian dimulai dengan melakukan pengamatan dan wawancara di perusahaan roti dan kue-kue ANDALAS. Pengamatan dilakukan terkait dengan permasalahan perusahaan dalam pemesanan bahan baku. Hal-hal terkait pemesanan bahan baku yang diperhatikan antara lain perhitungan pesanan bahan baku, sistem pemesanan bahan baku, proporsi penggunaan bahan baku, hasil penjualan, dan keuntungan yang didapatkan. Usulan sistem pengadaan bahan baku adalah sistem pengadaan bahan baku yang menghasilkan biaya terendah.

Identifikasi dan perumusan masalah dilakukan dengan melakukan pengamatan langsung dan wawancara terhadap perusahaan. Identifikasi masalah dilakukan untuk mengidentifikasi penerapan sistem sekarang. Batasan digunakan dalam penelitian dikarenakan data yang diberikan oleh pemilik usaha bersifat rahasia dan tidak diberikan secara menyeluruh. Data yang digunakan dalam penelitian ini adalah data pemesanan bahan baku jenis kue cake dengan sistem produksi make to stock dari bulan Januari 2017 hingga Desember 2019. Beberapa asumsi yang digunakan dalam penelitian ini antara lain: pemasok tetap memperoleh keuntungan dan dapat memenuhi permintaan pemesanan, pola estimasi permintaan mengikuti pola tahun 2017 hingga 2019 dengan perhitungan sesuai dengan persentase permintaan dan sisa Januari hingga Maret 2020, proporsi penggunaan bahan baku sesuai keterangan pemilik, serta tidak ada perubahan kondisi ekonomi.

Tujuan dari penelitian adalah mengetahui sistem pengadaan bahan baku utama berbasis kontrak pada perusahaan roti dan kue-kue ANDALAS untuk meminimasi total biaya bahan baku. Studi literatur untuk mempelajari lebih dalam hal-hal terkait sistem pengadaan bahan baku. Studi literatur dilakukan dengan mengumpulkan dan mempelajari teori terkait dengan manajemen rantai pasok, pembelian, serta penyusunan kontrak pasokan.

Beberapa data dibutuhkan untuk mengetahui sistem pengadaan bahan baku yang paling optimal, yaitu data jumlah produksi, data penjualan, data pemakaian bahan baku, data batch produksi, serta kapasitas ruang penyimpanan. Data historis yang digunakan 
merupakan data 2017 hingga 2019. Data tersebut kemudian diolah menggunakan metode optimasi dengan pemrograman linear dengan variabel keputusan kuantitas pembelian bahan baku pada pemasok. Kemudian dilakukan penentuan termin-termin kontrak yang menguntungkan perusahaan serta pemasok terkait.

Perbandingan sistem sekarang dan usulan dilakukan untuk melihat pengaruh pembelian bahan baku berbasis kontrak terhadap perolehan keuntungan perusahaan dan signifikansi perubahan yang dilakukan. Selain itu, analisis sensitivitas dilakukan untuk sistem usulan. Analisis sensitivitas dilakukan untuk mengetahui seberapa jauh perubahan dapat mempengaruhi penerapan sistem usulan.

Sistem usulan kemudian diterapkan dengan menggunakan hasil peramalan kebutuhan bahan baku dan rancangan usulan kontrak. Kesimpulan dan saran dapat diperoleh dari penelitian yang dilakukan sesuai dengan tujuan penelitian. Saran yang membangun diberikan untuk penelitian selanjutnya agar dapat berjalan lebih baik.

\section{Hasil dan Pembahasan}

Pada bagian ini akan diuraikan hasil penelitian disertai dengan pembahasannya.

\section{Pengumpulan dan Pengolahan Data Awal}

Data yang dibutuhkan dalam menentukan sistem pengadaan bahan baku berbasis kontrak pada perusahaan roti dan kue-kue ANDALAS antara lain data terkait produksi, penjualan, serta penyimpanan bahan baku. Data didapatkan dari hasil pengamatan dan wawancara pada perusahaan. Batch produksi dapat dilihat pada Tabel 1.

Tabel 1. Batch produksi (buah)

\begin{tabular}{|c|c|c|}
\hline Nama Produk & $\begin{array}{c}\text { Kode } \\
\text { Produk }\end{array}$ & $\begin{array}{c}\text { Batch } \\
\text { Produksi }\end{array}$ \\
\hline Cake Kacang & P-1 & 25 \\
\hline Cake Almond & P-2 & 25 \\
\hline Cake Marmer Kering & P-3 & 25 \\
\hline Duck Cake & P-4 & 20 \\
\hline Basket /Bag Cake & P-5 & 20 \\
\hline Cake Hati & P-6 & 20 \\
\hline Amandel & P-7 & 25 \\
\hline Bangket Kenari & P-8 & 15 \\
\hline
\end{tabular}

Bahan baku yang dibutuhkan untuk masingmasing kue beraneka ragam. Penggolongan bahan baku utama membutuhkan data kebutuhan bahan baku per batch dapat dilihat pada Tabel 2. Kebutuhan bahan baku nantinya akan digunakan dalam perhitungan total kebutuhan bahan baku.

Tabel 2. Kebutuhan bahan baku per batch

\begin{tabular}{|r|c|c|c|c|c|c|c|}
\hline \multicolumn{7}{|c|}{ Bahan Baku } \\
P \\
$\begin{array}{r}\text { r } \\
\text { d } \\
\text { u } \\
\text { k }\end{array}$
\end{tabular}

Kebutuhan bahan baku pada Tabel 2 dinyatakan dalam kilogram, kecuali telur ayam dinyatakan dalam butir. Pengadaan bahan baku perlu memperhatikan kapasitas penyimpanan. Ruang penyimpanan diatur secara dedicated storage untuk masing-masing jenis bahan baku. Penyimpanan bahan baku menjadi salah satu batasan yang perlu diperhatikan dalam perencanaan pemenuhan kebutuhan bahan baku. Kapasitas bahan baku dapat dilihat pada Tabel 3 dengan unit satuan kilogram kecuali telur ayam dalam butir. 
Tabel 3. Kapasitas ruang penyimpanan

\begin{tabular}{|c|c|}
\hline Jenis Bahan Baku & Jumlah (Unit Satuan) \\
\hline Tepung Terigu & 250 \\
\hline Tepung Maizena & 48 \\
\hline Bubuk pengembang & 60 \\
\hline Mentega & 30 \\
\hline Gula Halus & 120 \\
\hline Margarin Putih & 40 \\
\hline Telur Ayam & 225 \\
\hline
\end{tabular}

Data historis yang digunakan dalam penelitian ini adalah data penjualan dan produksi selama tahun 2017 hingga 2019 yang telah disesuaikan dengan data persentase permintaan dan sisa. Penyesuaian mengikuti persentase permintaan dan sisa pada Tabel 4 . Sisa merupakan produk gagal ataupun bahan baku yang tidak lagi layak digunakan untuk produksi kue.

Tabel 4. Persentase permintaan dan sisa (D: Permintaan; W: Sisa; P: Produksi)

\begin{tabular}{|c|c|c|c|}
\hline Jenis Produk & D/P & W/P & Total \\
\hline Cake Kacang & $\begin{array}{c}104,79 \\
\%\end{array}$ & $\begin{array}{c}4,13 \\
\%\end{array}$ & $\begin{array}{c}108,92 \\
\%\end{array}$ \\
\hline Cake Almond & $\begin{array}{c}104,66 \\
\%\end{array}$ & $\begin{array}{c}0,58 \\
\%\end{array}$ & $\begin{array}{c}105,24 \\
\%\end{array}$ \\
\hline $\begin{array}{c}\text { Cake } \\
\text { Marmer Kering }\end{array}$ & $\begin{array}{c}104,40 \\
\%\end{array}$ & $\begin{array}{c}0,00 \\
\%\end{array}$ & $\begin{array}{c}104,40 \\
\%\end{array}$ \\
\hline Duck Cake & $\begin{array}{c}102,73 \\
\%\end{array}$ & $\begin{array}{c}0,93 \\
\%\end{array}$ & $\begin{array}{c}103,66 \\
\%\end{array}$ \\
\hline $\begin{array}{c}\text { Basket /Bag } \\
\text { Cake }\end{array}$ & $\begin{array}{c}103,11 \\
\%\end{array}$ & $\begin{array}{c}0,99 \\
\%\end{array}$ & $\begin{array}{c}104,10 \\
\%\end{array}$ \\
\hline Cake Hati & $\begin{array}{c}107,95 \\
\%\end{array}$ & $\begin{array}{c}1,03 \\
\%\end{array}$ & $\begin{array}{c}108,97 \\
\%\end{array}$ \\
\hline Amandel & $\begin{array}{c}102,82 \\
\%\end{array}$ & $\begin{array}{c}0,80 \\
\%\end{array}$ & $\begin{array}{c}103,62 \\
\%\end{array}$ \\
\hline Bangket Kenari & $\begin{array}{c}102,82 \\
\%\end{array}$ & $\begin{array}{c}0,43 \\
\%\end{array}$ & $\begin{array}{c}103,25 \\
\%\end{array}$ \\
\hline
\end{tabular}

Permintaan total pasar yang telah disesuaikan dengan permintaan dan sisa akan diubah menjadi estimasi kebutuhan bahan baku sesuai dengan keterangan pada Tabel 2 . Estimasi pemakaian bahan baku dapat dilihat pada Gambar 1 memiliki kecenderungan pola musiman.

Pola musiman terjadi pada awal tahun, tengah tahun, dan akhir tahun. Pola tersebut merupakan mengikuti hari raya yang ada di Indonesia. Secara keseluruhan pemakaian bahan baku memiliki pola data tren setiap tahunnya. Hal ini dapat dilihat pada Gambar 2.

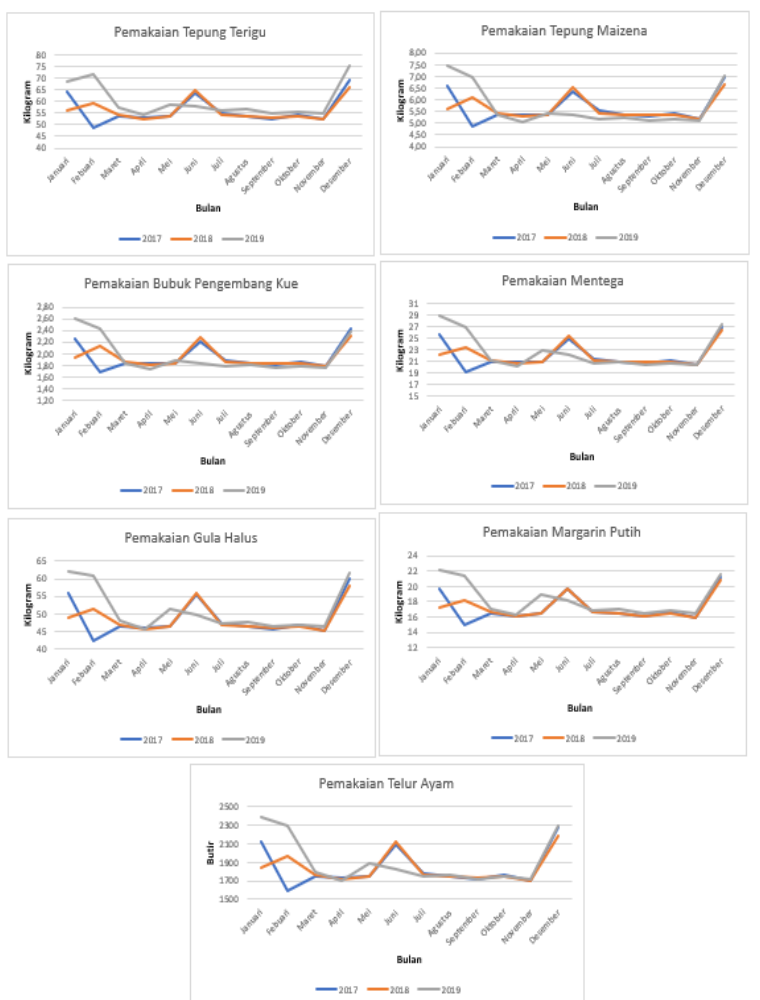

Gambar 1. Grafik pemakaian bahan baku per bulan

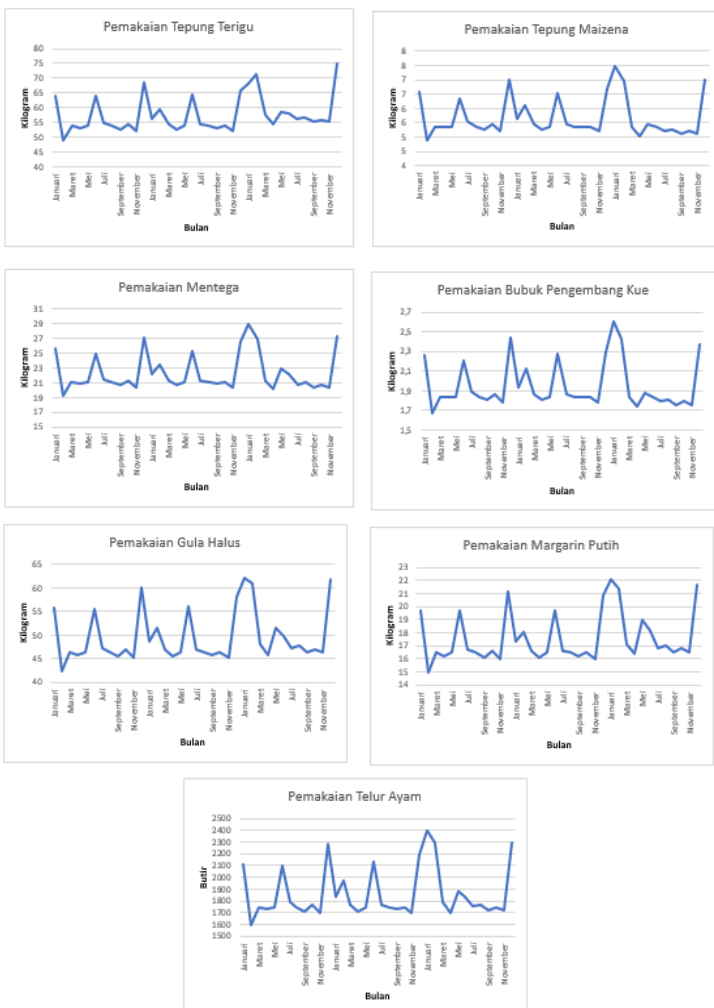

Gambar 2. Grafik pemakaian bahan baku gabungan

\section{Peramalan Kebutuhan Bahan Baku}

Peramalan kebutuhan bahan baku dilakukan sesuai dengan pola data historis yang memiliki kecenderungan pola data musiman 
dan tren. Peramalan dilakukan dengan menggunakan 4 metode peramalan yaitu regresi linear, time series decomposition, three moving averages, dan Winter's three factor model. Metode peramalan terpilih untuk peramalan kebutuhan bahan baku adalah Winter's three factor model dengan membandingkan 4 metode peramalan yang memiliki nilai paling minimum untuk Mean Error (ME), Mean Absolute Error (MAE), Mean Squared Error (MSE), Mean Percentage Error (MPE), dan Mean Absolute Percentage Error (MAPE).

Pemilihan metode peramalan dilakukan untuk masing-masing bahan baku. Hasil perhitungan error dapat dilihat pada Tabel 5. Pemilihan dilakukan dengan melihat tingkat error paling kecil seperti contohnya pada telur ayam, error terkecil dimiliki oleh metode Winter's Three Factor dengan nilai paling kecil MSE, MAE, dan MAPE. Metode peramalan terpilih untuk semua jenis bahan baku adalah metode Winter's three factor.

Tabel 5. Perbandingan tingkat error Tepung Terigu

\begin{tabular}{|l|r|r|r|r|r|}
\hline & \multicolumn{1}{|c|}{ ME } & \multicolumn{1}{c|}{ MSE } & \multicolumn{1}{c|}{ MPE } & \multicolumn{1}{c|}{ MAE } & \multicolumn{1}{c|}{ MAPE } \\
\hline Regresi & 0,00 & 34,42 & $-0,93 \%$ & 4,70 & $7,83 \%$ \\
\hline Seasona & $-0,74$ & 63,55 & $-1,32 \%$ & 4,40 & $7,38 \%$ \\
\hline 3MA & 0,69 & 50,95 & $0,23 \%$ & 5,00 & $8,13 \%$ \\
\hline Winter & 0,79 & 24,15 & $0,96 \%$ & 3,00 & $4,80 \%$ \\
\hline MIN & $-0,74$ & 24,15 & $-1,32 \%$ & 3,00 & $4,80 \%$ \\
\hline
\end{tabular}

\section{Tepung Maizena}

\begin{tabular}{|l|r|r|r|r|r|}
\hline & \multicolumn{1}{|c|}{ ME } & \multicolumn{1}{c|}{ MSE } & \multicolumn{1}{c|}{ MPE } & \multicolumn{1}{c|}{ MAE } & \multicolumn{1}{c|}{ MAPE } \\
\hline Regresi & 0,00 & 0,44 & $-1,22 \%$ & 0,54 & $9,09 \%$ \\
\hline Seasona & $-0,07$ & 0,62 & $-1,39 \%$ & 0,45 & $7,78 \%$ \\
\hline 3 MA & 0,04 & 0,64 & $-0,48 \%$ & 0,55 & $9,20 \%$ \\
\hline Winter & 0,03 & 0,37 & $-0,14 \%$ & 0,36 & $5,89 \%$ \\
\hline MIN & $-0,07$ & 0,37 & $-1,39 \%$ & 0,36 & $5,89 \%$ \\
\hline
\end{tabular}

\section{Bubuk Pengembang Kue}

\begin{tabular}{|l|r|r|r|r|r|}
\hline & \multicolumn{1}{|c|}{ ME } & \multicolumn{1}{c|}{ MSE } & \multicolumn{1}{c|}{ MPE } & \multicolumn{1}{c|}{ MAE } & \multicolumn{1}{c|}{ MAPE } \\
\hline Regresi & 0,00 & 0,06 & $-1,30 \%$ & 0,19 & $9,45 \%$ \\
\hline Seasona & $-0,02$ & 0,07 & $-1,41 \%$ & 0,15 & $7,75 \%$ \\
\hline 3MA & 0,01 & 0,08 & $-0,63 \%$ & 0,20 & $9,71 \%$ \\
\hline Winter & 0,01 & 0,04 & $-0,14 \%$ & 0,13 & $5,98 \%$ \\
\hline MIN & $-0,02$ & 0,04 & $-1,41 \%$ & 0,13 & $5,98 \%$ \\
\hline
\end{tabular}

\section{Mentega}

\begin{tabular}{|l|r|r|r|r|r|}
\hline & \multicolumn{1}{|c|}{ ME } & \multicolumn{1}{c|}{ MSE } & \multicolumn{1}{c|}{ MPE } & \multicolumn{1}{c|}{ MAE } & \multicolumn{1}{c|}{ MAPE } \\
\hline Regresi & 0,00 & 6,03 & $-1,09 \%$ & 1,99 & $8,58 \%$ \\
\hline Seasona & $-0,29$ & 9,58 & $-1,33 \%$ & 1,74 & $7,54 \%$ \\
\hline 3MA & 0,17 & 8,91 & $-0,34 \%$ & 2,07 & $8,79 \%$ \\
\hline Winter & 0,24 & 4,33 & $0,58 \%$ & 1,21 & $5,03 \%$ \\
\hline MIN & $-0,29$ & 4,33 & $-1,33 \%$ & 1,21 & $5,03 \%$ \\
\hline
\end{tabular}

Gula Halus

\begin{tabular}{|l|r|r|r|r|r|}
\hline & \multicolumn{1}{|c|}{ ME } & \multicolumn{1}{c|}{ MSE } & \multicolumn{1}{c|}{ MPE } & \multicolumn{1}{c|}{ MAE } & \multicolumn{1}{c|}{ MAPE } \\
\hline Regresi & 0,00 & 27,84 & $-1,02 \%$ & 4,31 & $8,35 \%$ \\
\hline Seasona & $-0,65$ & 46,85 & $-1,31 \%$ & 3,80 & $7,41 \%$ \\
\hline 3MA & 0,46 & 41,71 & $-0,12 \%$ & 4,54 & $8,64 \%$ \\
\hline Winter & 1,01 & 19,84 & $1,59 \%$ & 2,52 & $4,62 \%$ \\
\hline MIN & $-0,65$ & 19,84 & $-1,31 \%$ & 2,52 & $4,62 \%$ \\
\hline
\end{tabular}

(lanjut)
Tabel 5. Perbandingan tingkat error (lanjutan)

\section{Margarin Putih}

\begin{tabular}{|l|r|r|r|r|r|}
\hline & \multicolumn{1}{|c|}{ ME } & \multicolumn{1}{c|}{ MSE } & \multicolumn{1}{c|}{ MPE } & \multicolumn{1}{c|}{ MAE } & \multicolumn{1}{c|}{ MAPE } \\
\hline Regresi & 0,00 & 3,38 & $-0,99 \%$ & 1,52 & $8,32 \%$ \\
\hline Seasona & $-0,24$ & 5,95 & $-1,29 \%$ & 1,35 & $7,38 \%$ \\
\hline 3MA & 0,16 & 5,09 & $-0,13 \%$ & 1,63 & $8,76 \%$ \\
\hline Winter & 0,33 & 2,32 & $1,49 \%$ & 0,82 & $4,23 \%$ \\
\hline MIN & $-0,24$ & 2,32 & $-1,29 \%$ & 0,82 & $4,23 \%$ \\
\hline
\end{tabular}

\section{Telur Ayam}

\begin{tabular}{|l|r|r|r|r|r|}
\hline & \multicolumn{1}{|c|}{ ME } & \multicolumn{1}{c|}{ MSE } & \multicolumn{1}{c|}{ MPE } & \multicolumn{1}{c|}{ MAE } & \multicolumn{1}{c|}{ MAPE } \\
\hline Regresi & 0,00 & 42944,50 & $-1,11 \%$ & 168,51 & $8,66 \%$ \\
\hline Seasona & $-24,11$ & 66053,55 & $-1,33 \%$ & 143,64 & $7,48 \%$ \\
\hline 3MA & 15,41 & 64101,77 & $-0,30 \%$ & 177,90 & $9,01 \%$ \\
\hline Winter & 34,29 & 31986,76 & $1,33 \%$ & 101,09 & $4,94 \%$ \\
\hline MIN & $-24,11$ & 31986,76 & $-1,33 \%$ & 101,09 & $4,94 \%$ \\
\hline
\end{tabular}

Tabel 6. Estimasi kebutuhan bahan baku

\begin{tabular}{|c|c|c|c|c|c|c|}
\hline \multicolumn{2}{|c|}{ Periode } & \multicolumn{5}{|c|}{ Jenis Bahan Baku } \\
\hline Thn & Bulan & $\begin{array}{l}\text { Tepung } \\
\text { Terigu }\end{array}$ & $\begin{array}{l}\text { Tept } \\
\text { Maiz }\end{array}$ & & $\begin{array}{c}\text { Bubuk } \\
\text { pengem } \\
\text { bang } \\
\text { kue }\end{array}$ & Mentega \\
\hline \multirow[t]{6}{*}{2020} & Juli & 59,49 & 5,5 & & 16,73 & 10,41 \\
\hline & Agustus & 60,32 & 5,3 & & 16,63 & 10,52 \\
\hline & September & 58,64 & 5,3 & & 16,35 & 10,22 \\
\hline & Oktober & 59,20 & 5,4 & & 16,60 & 10,41 \\
\hline & November & 58,74 & 5,2 & & 16,16 & 10,22 \\
\hline & Desember & 80,10 & 7,0 & & 21,61 & 13,72 \\
\hline \multirow[t]{12}{*}{2021} & Januari & 77,52 & 6,6 & & 21,45 & 14,52 \\
\hline & Februari & 81,12 & 5,0 & & 19,72 & 13,51 \\
\hline & Maret & 65,12 & 5,3 & & 16,82 & 10,65 \\
\hline & April & 61,50 & 5,4 & & 16,29 & 10,12 \\
\hline & Mei & 66,25 & 5,3 & & 16,93 & 11,48 \\
\hline & Juni & 65,26 & 6,3 & & 18,71 & 11,11 \\
\hline & Juli & 63,22 & 5,5 & & 16,76 & 10,44 \\
\hline & Agustus & 64,08 & 5,3 & & 16,66 & 10,56 \\
\hline & September & 62,28 & 5,3 & & 16,38 & 10,25 \\
\hline & Oktober & 62,85 & 5,4 & & 16,63 & 10,44 \\
\hline & November & 62,34 & 5,2 & & 16,19 & 10,26 \\
\hline & Desember & 84,98 & 7,0 & & 21,66 & 13,76 \\
\hline \multicolumn{2}{|r|}{ Periode } & \multicolumn{5}{|c|}{ Jenis Bahan Baku } \\
\hline Thn & Bulan & Gula & lalus & & $\begin{array}{l}\text { garin } \\
\text { utih }\end{array}$ & Telur Ayam \\
\hline \multirow[t]{6}{*}{2020} & Juli & \multicolumn{2}{|c|}{48,08} & & 7,41 & 125,20 \\
\hline & Agustus & \multicolumn{2}{|c|}{48,60} & &, 55 & 126,59 \\
\hline & September & \multicolumn{2}{|c|}{47,18} & & 7,02 & 122,91 \\
\hline & Oktober & \multicolumn{2}{|c|}{47,93} & & 7,34 & 124,91 \\
\hline & November & \multicolumn{2}{|c|}{47,19} & & 7,02 & 122,91 \\
\hline & Desember & \multicolumn{2}{|c|}{62,92} & & 2,33 & 164,26 \\
\hline \multirow[t]{12}{*}{2021} & Januari & \multicolumn{2}{|c|}{64,43} & & 3,53 & 171,40 \\
\hline & Februari & \multicolumn{2}{|c|}{63,13} & & 2,83 & 164,75 \\
\hline & Maret & \multicolumn{2}{|c|}{49,98} & & 8,28 & 128,18 \\
\hline & April & \multicolumn{2}{|c|}{47,50} & & 7,44 & 121,72 \\
\hline & Mei & \multicolumn{2}{|c|}{53,32} & & 0,22 & 135,09 \\
\hline & Juni & \multicolumn{2}{|c|}{51,63} & & 9,31 & 131,36 \\
\hline & Juli & \multicolumn{2}{|c|}{48,95} & & 7,96 & 125,42 \\
\hline & Agustus & \multicolumn{2}{|c|}{49,47} & & 8,11 & 126,81 \\
\hline & September & \multicolumn{2}{|c|}{48,03} & & 7,56 & 123,12 \\
\hline & Oktober & & & 7,89 & 125,12 \\
\hline & November & & & & 7,56 & 123,12 \\
\hline & Desember & \multicolumn{2}{|c|}{64,05} & & 3,03 & 164,54 \\
\hline
\end{tabular}

\section{Penyusunan Model Matematis}

Pembelian kebutuhan bahan baku dapat dioptimasi dengan menggunakan suatu persamaan linear. Tujuan dari persamaan linear adalah meminimasi total biaya pembelian bahan baku pada pemasok. Pengambilan keputusan jumlah pembelian bahan baku ditentukan setiap awal bulannya pada perusahaan roti dan kue-kue ANDALAS. Pengambilan keputusan dipengaruhi oleh 
harga jual pemasok serta perubahan permintaan. Model dibuat untuk tipe pembelian grosir kelipatan dan tipe pembelian grosir minimum.

\section{Model Matematis untuk Harga Grosir Kelipatan (Model 1)}

\section{Fungsi Tujuan:}

meminimasi biaya pembelian bahan baku (tepung terigu, gula halus, margarin putih, dan telur)

$$
z_{b}=\sum_{t=7}^{t=24}\left\{m \mathrm{P}_{w} \mathrm{Q}_{w t}+\sum_{s=1}^{6} \mathrm{P}_{\mathrm{u}} \mathrm{Q}_{\mathrm{ut}}\right\} \quad \text { Pers. } 1
$$

$z_{b}$ : Total biaya yang dikeluarkan untuk pembelian jenis bahan baku $b$

\section{Parameter dan Indeks:}

$\mathrm{P}_{w} \quad$ Harga untuk pembelian satuan grosir

$\mathrm{P}_{\mathrm{u}} \quad$ Harga untuk pembelian satuan unit

SS Persediaan pengaman

$\mathrm{m} \quad$ Satuan pembelian grosir

$I_{\mathrm{t}-1} \quad$ Persediaan pada periode $\mathrm{t}-1$

C Kapasitas penyimpanan bahan baku

$D_{\mathrm{t}} \quad$ Kebutuhan bahan baku pada periode $\mathrm{t}$

s Pemasok s

\section{Variabel Keputusan:}

$\mathrm{Q}_{\mathrm{wt}} \quad$ Jumlah pembelian satuan grosir pada periode ke $t$

$Q_{u t} \quad$ Jumlah pembelian satuan unit pada periode ke $\mathrm{t}$

\section{Batasan Persamaan:}

\begin{tabular}{|c|c|c|}
\hline $\mathrm{Q}_{\mathrm{ut}} \leq \mathrm{m}$ & $\begin{array}{l}\text { Lebih dari } \\
\text { m akan } \\
\text { dibeli } \\
\text { secara } \\
\text { grosir }\end{array}$ & Pers. 2 \\
\hline $\mathrm{Q}_{\mathrm{ut}}+\mathrm{mQ}_{\mathrm{wt}}+I_{\mathrm{t}-1} \geq \mathrm{SS}$ & $\begin{array}{l}\text { Constraint } \\
\text { memenuhi } \\
\text { Persediaa } \\
\mathrm{n} \\
\text { pengaman }\end{array}$ & Pers. 3 \\
\hline $\mathrm{Q}_{\mathrm{ut}}+\mathrm{mQ}_{\mathrm{wt}}+I_{\mathrm{t}-1} \leq C$ & $\begin{array}{l}\text { Constraint } \\
\text { memenuhi } \\
\text { Kapasitas } \\
\text { Penyimpa } \\
\text { nan }\end{array}$ & Pers. 4 \\
\hline $\mathrm{Q}_{\mathrm{ut}}+\mathrm{mQ}_{\mathrm{wt}}+I_{\mathrm{t}-1} \geq D$ & $\begin{array}{l}\text { Constraint } \\
\text { memenuhi } \\
\text { Permintaa } \\
\mathrm{n}\end{array}$ & Pers. 5 \\
\hline
\end{tabular}

$\mathrm{Q}_{\mathrm{ut}}, \mathrm{Q}_{\mathrm{wt}}, I_{\mathrm{t}-1}, \mathrm{SS} \geq 0 \in$ integer

Pers. 6

\section{Model Matematis untuk Harga Grosir Minimum (Model 2) \\ Fungsi Tujuan:}

meminimasi biaya pembelian bahan baku (tepung maizena, bubuk pengembang kue, dan mentega)

$$
z_{b}=\sum_{t=7}^{t=24}\left\{T P(x)+\sum_{s=2}^{7} \mathrm{P}_{\mathrm{u}} \mathrm{Q}_{\mathrm{ut}}\right\} \quad \text { Pers. } 7
$$

$z_{b}$ : Total biaya yang dikeluarkan untuk pembelian jenis bahan baku $b$

$T P(x)=\left\{\begin{array}{lc}P_{u A} x & (0 \leq \mathrm{x} \leq \mathrm{m}-1) \\ P_{w A} x & (\mathrm{~m} \leq \mathrm{x} \leq \mathrm{M})\end{array} \quad\right.$ Pers. 8

\section{Parameter dan Indeks:}

$T P(x) \quad$ Total harga untuk $\mathrm{x}$ unit di pemasok A

$P_{u A} \quad$ Harga untuk pembelian satuan unit pemasok $A$

$P_{w A} \quad$ Harga untuk pembelian satuan grosir pemasok $A$

SS Persediaan pengaman

m Satuan pembelian minimal grosir

$I_{\mathrm{t}-1} \quad$ Persediaan pada periode $\mathrm{t}-1$

C Kapasitas penyimpanan bahan baku

$D_{\mathrm{t}} \quad$ Kebutuhan bahan baku pada periode $t$

s Pemasok s

\section{Variabel Keputusan:}

$\mathrm{Q}_{\mathrm{ut}} \quad$ Jumlah pembelian satuan unit pada periode ke $\mathrm{t}$

$x_{t} \quad$ Jumlah unit yang dibeli di pemasok A pada periode ke $t$

\section{Batasan Persamaan:}

$\begin{array}{lll}\mathrm{Q}_{\mathrm{ut}} \leq \mathrm{m} & \begin{array}{l}\text { Lebih dari } \\ \text { m akan } \\ \text { dibeli } \\ \text { secara }\end{array} & \\ \mathrm{Q}_{\mathrm{ut}}+T P w t+I_{\mathrm{t}-1} \geq \mathrm{SS} & \begin{array}{l}\text { grosir } \\ \text { Constraint } \\ \text { memenuhi }\end{array} & \text { Pers. 10 } \\ & \begin{array}{l}\text { Persediaan } \\ \text { pengaman }\end{array} \\ \mathrm{Q}_{\mathrm{ut}}+T P w t+I_{\mathrm{t}-1} \leq C & \begin{array}{l}\text { Constraint } \\ \text { memenuhi }\end{array} & \text { Pers. 11 } \\ & \begin{array}{l}\text { Kapasitas } \\ \text { Penyimpan } \\ \text { an }\end{array} & \\ \mathrm{Q}_{\mathrm{ut}}+T P w t+I_{\mathrm{t}-1} \geq D_{\mathrm{t}} & \begin{array}{l}\text { Constraint } \\ \text { memenuhi }\end{array} & \text { Pers. 12 } \\ & \begin{array}{l}\text { Permintaa } \\ \mathrm{n}\end{array} \\ \mathrm{Q}_{\mathrm{ut}}, T P w t, I_{\mathrm{t}-1,1} \mathrm{SS} \geq 0 \in \text { integer } & \text { Pers. 13 }\end{array}$


$x_{t} \geq 0$

Pers. 14

\section{Perbandingan Pengadaan Bahan Baku Awal dan Usulan}

Model matematis diterapkan untuk permintaan dan harga bahan baku pada tahun 2017 hingga 2019. Perbandingan dilihat dari biaya yang dibutuhkan dengan penentuan kuantitas menggunakan insting dan penerapan model. Data pembelian bahan baku awal diperoleh dari wawancara sedangkan pembelian bahan baku usulan menggunakan keputusan model matematis. Rekapitulasi pengadaan bahan baku awal dan usulan dapat dilihat pada Tabel 7 .

Tabel 7. Rekapitulasi pengadaan bahan baku awal dan usulan

\begin{tabular}{|c|c|c|}
\hline $\begin{array}{c}\text { Bahan } \\
\text { Baku }\end{array}$ & $\begin{array}{c}\text { Biaya } \\
\text { Pengadaan } \\
\text { Bahan Baku } \\
\text { Awal }\end{array}$ & $\begin{array}{c}\text { Biaya } \\
\text { Pengadaan } \\
\text { Bahan Baku } \\
\text { Usulan }\end{array}$ \\
\hline Tepung Terigu & Rp19.905.000 & Rp19.056.000 \\
\hline Tepung Maizena & Rp7.800.000 & Rp6.528.400 \\
\hline $\begin{array}{c}\text { Bubuk } \\
\text { pengembang kue }\end{array}$ & Rp8.940.000 & Rp7.911.200 \\
\hline Mentega & Rp12.305.500 & Rp11.428.500 \\
\hline Gula Halus & Rp28.605.000 & Rp26.912.000 \\
\hline Margarin Putih & Rp20.048.220 & Rp17.468.205 \\
\hline Telur Ayam & Rp112.852.500 & Rp107.892.500 \\
\hline Total & Rp210.456.220 & Rp197.196.805 \\
\hline
\end{tabular}

Penurunan biaya masing-masing pengadaan bahan baku dengan model linear dapat dilihat pada Tabel 8. Persentase penurunan biaya secara keseluruhan adalah $6,30 \%$ dari biaya pengadaan bahan baku awal. Penghematan total yang diperoleh selama 3 tahun adalah sebesar Rp.13.259.415,-.

Tabel 8. Rekapitulasi penghematan pengadaan bahan baku usulan

\begin{tabular}{|c|c|c|}
\hline Bahan Baku & Penurunan (Rp) & $\%$ \\
\hline Tepung Terigu & Rp849.000 & $4,27 \%$ \\
\hline Tepung Maizena & Rp1.271.600 & $16,30 \%$ \\
\hline Bubuk pengembang kue & Rp1.028.800 & $11,51 \%$ \\
\hline Mentega & Rp877.000 & $7,13 \%$ \\
\hline Gula Halus & Rp1.693.000 & $5,92 \%$ \\
\hline Margarin Putih & Rp2.580.015 & $12,87 \%$ \\
\hline Telur Ayam & Rp4.960.000 & $4,40 \%$ \\
\hline Total & Rp13.259.415 & $6,30 \%$ \\
\hline
\end{tabular}

Pengadaan bahan baku awal sebagian besar didapatkan dari pemasok utama. Pembelian pada pemasok lain dilakukan sebanyak $0,76 \%$ dari total keseluruhan pembelian. Rekapitulasi pembelian dapat dilihat pada Tabel 9. Risiko pembelian tidak dapat dipenuhi pemasok utama adalah sebesar $0,76 \%$.

Tabel 9. Proporsi pembelian bahan baku

\begin{tabular}{|l|r|}
\hline $\begin{array}{l}\text { Pembelian Grosir pada Pemasok } \\
\text { Utama }\end{array}$ & Rp204.082.720 \\
\hline $\begin{array}{l}\text { Pembelian Satuan pada Pemasok } \\
\text { Utama }\end{array}$ & $\mathrm{Rp} 4.765 .000$ \\
\hline Pembelian pada Pemasok Lain & $\mathrm{Rp} 1.608 .500$ \\
\hline Total & $\mathrm{Rp} 210.456 .220$ \\
\hline
\end{tabular}

\section{Penyusunan Kontrak Pengadaan Bahan Baku}

Kontrak dibuat atas kesepakatan hak dan kewajiban yang harus dipenuhi antara dua atau lebih pihak yang menyetujuinya. Dalam penyusunan kontrak perlu diperhatikan kapasitas dan kebutuhan dari kedua belah pihak. Penyusunan kontrak dilakukan sedemikian rupa dengan persetujuan kedua belah pihak untuk memberikan keuntungan yang setara bagi keduanya.

Rancangan usulan kontrak yang diberikan oleh perusahaan roti dan kue-kue ANDALAS terhadap pemasok bersifat semi fleksibel dengan memperhatikan kebutuhan kedua belah pihak. Pasal-pasal dalam kontrak dibuat sesuai dengan negosiasi antar pihak dan disahkan dengan menggunakan materai. Detail pasal dalam rancangan usulan kontrak dapat dilihat pada Tabel 10.

Jenis kontrak yang digunakan adalah kontrak portofolio dengan jenis produk dalam kontrak barang strategis. Kontrak dilakukan dalam jangka menengah yaitu dengan periode kontrak selama 1,5 tahun. Penetapan periode ini sesuai dengan pengambilan keputusan perencanaan persediaan pada level taktis yang secara umum dilakukan selama rentang waktu 12-24 bulan. Penentuan kuantitas pembelian dilakukan dengan menggunakan model matematis yang telah disusun sebelumnya. Rekapitulasi kuantitas pembelian selama periode kontrak dapat dilihat pada Tabel 11.

Rencana pembelian dilakukan dengan tujuan minimasi total biaya bahan baku selama periode kontrak. Dari table 11, dapat terlihat pembelian secara total adalah $1175 \mathrm{~kg}$ tepung terigu, 103 pak tepung maizena, 319 pak bubuk pengembang kue, 203 pak mentega, $940 \mathrm{~kg}$ gula halus, $330 \mathrm{~kg}$ margarin putih, dan 2415 kilogram telur ayam. Penentuan kebutuhan bahan baku dilakukan dengan melakukan 
peramalan permintaan kebutuhan bahan baku menggunakan data 3 tahun sebelum. Total biaya yang dikeluarkan untuk pembelian dari bulan Juli 2020 hingga Desember 2021 dapat dilihat pada Tabel 12 .

Tabel 10. Detail pasal dalam rancangan usulan kontrak

\begin{tabular}{|c|l|l|}
\hline $\begin{array}{c}\text { Pasal } \\
\text { ke- }\end{array}$ & \multicolumn{1}{|c|}{ Isi Pasal } & \multicolumn{1}{|c|}{ Keterangan } \\
\hline 1 & Jenis Barang & $\begin{array}{l}\text { Produk yang akan } \\
\text { diperjualbelikan oleh } \\
\text { kedua belah pihak }\end{array}$ \\
\hline 2 & Harga Barang & $\begin{array}{l}\text { Harga yang ditawarkan } \\
\text { oleh pemasok utama }\end{array}$ \\
\hline 3 & $\begin{array}{l}\text { Kuantitas } \\
\text { Pembelian }\end{array}$ & $\begin{array}{l}\text { Ketentuan kuantitas } \\
\text { tiap bulan yang } \\
\text { disetujui pembayaran }\end{array}$ \\
\hline 4 & $\begin{array}{l}\text { Cara } \\
\text { Pembayaran }\end{array}$ & $\begin{array}{l}\text { Cara ditawarkan } \\
\text { yang diterima } \\
\text { pemasok dan } \\
\text { oleh pembeli }\end{array}$ \\
\hline 5 & $\begin{array}{l}\text { Pengiriman } \\
\text { Barang }\end{array}$ & $\begin{array}{l}\text { Ketentuan pengiriman } \\
\text { barang beserta kondisi } \\
\text { barang yang dikirimkan }\end{array}$ \\
\hline 6 & $\begin{array}{l}\text { Sanksi Atas } \\
\text { Keterlambatan } \\
\text { Pengiriman } \\
\text { Barang }\end{array}$ & $\begin{array}{l}\text { Sanksi keterlambatan } \\
\text { ditentukan agar } \\
\text { pengiriman pesanan } \\
\text { tidak menyebabkan } \\
\text { keterlambatan }\end{array}$ \\
\hline 7 & $\begin{array}{l}\text { Penyelesaian } \\
\text { Perselisihan }\end{array}$ & $\begin{array}{l}\text { Perselisihan akan } \\
\text { diselesaikan dengan } \\
\text { persetujuan }\end{array}$ \\
\hline
\end{tabular}

Tabel 11. Rekapitulasi pembelian selama periode kontrak (kilogram)

\begin{tabular}{|c|c|c|c|c|c|c|c|}
\hline \multirow{2}{*}{ Periode* } & \multicolumn{7}{|c|}{ Bahan Baku } \\
\hline & 1 & 2 & 3 & 4 & 5 & 6 & 7 \\
\hline 1 & 275 & 27 & 17 & 38 & 160 & 45 & 315 \\
\hline 2 & 75 & 0 & 17 & 0 & 40 & 15 & 135 \\
\hline 3 & 50 & 0 & 16 & 0 & 50 & 15 & 120 \\
\hline 4 & 50 & 0 & 17 & 31 & 50 & 30 & 120 \\
\hline 5 & 50 & 0 & 16 & 10 & 30 & 0 & 120 \\
\hline 6 & 100 & 54 & 22 & 14 & 60 & 30 & 165 \\
\hline 7 & 75 & 0 & 21 & 0 & 70 & 30 & 165 \\
\hline 8 & 50 & 0 & 20 & 7 & 70 & 0 & 165 \\
\hline 9 & 75 & 0 & 17 & 5 & 50 & 30 & 135 \\
\hline 10 & 75 & 22 & 16 & 37 & 50 & 15 & 120 \\
\hline 11 & 50 & 0 & 31 & 11 & 50 & 30 & 135 \\
\hline 12 & 50 & 0 & 32 & 0 & 60 & 0 & 120 \\
\hline 13 & 100 & 0 & 46 & 5 & 50 & 15 & 135 \\
\hline 14 & 50 & 0 & 0 & 5 & 50 & 30 & 120 \\
\hline 15 & 50 & 0 & 0 & 6 & 40 & 15 & 135 \\
\hline 16 & 0 & 0 & 0 & 10 & 40 & 15 & 120 \\
\hline 17 & 0 & 0 & 31 & 24 & 20 & 15 & 75 \\
\hline 18 & 0 & 0 & 0 & 0 & 0 & 0 & 15 \\
\hline
\end{tabular}

Tabel 12. Rekapitulasi rencana biaya pengadaan bahan baku dalam kontrak

\begin{tabular}{|c|c|}
\hline Jenis Bahan Baku & $\begin{array}{c}\text { Biaya Pengadaan } \\
\text { Bahan Baku }\end{array}$ \\
\hline Tepung Terigu & $\mathrm{Rp} 10.746 .000,00$ \\
\hline Tepung Maizena & $\mathrm{Rp} 3.682 .250,00$ \\
\hline Bubuk pengembang kue & $\mathrm{Rp} 6.699 .000,00$ \\
\hline Mentega & $\mathrm{Rp} 6.090 .000,00$ \\
\hline Gula Halus & $\mathrm{Rp} 6.345 .000,00$ \\
\hline Margarin Putih & $\mathrm{Rp} 8.588 .000,00$ \\
\hline Telur Ayam & $\mathrm{Rp} 46.184 .000,00$ \\
\hline Total & $\mathrm{Rp} 88.334 .250,00$ \\
\hline
\end{tabular}

\section{Analisis Sensitivitas}

Analisis sensitivitas dilakukan untuk mengetahui seberapa besar pengaruh dari perubahan parameter terhadap biaya pengadaan bahan baku dan penerapan model. Parameter yang diperhatikan dalam penelitian ini adalah perubahan permintaan dan perubahan harga. Perubahan permintaan akan mempengaruhi kebutuhan bahan baku yang diperlukan oleh perusahaan roti dan kue-kue ANDALAS. Kemungkinan permintaan dapat mengalami kenaikan atau penurunan. Pengaruh permintaan terhadap perubahan parameter permintaan mulai dari di bawah 50\% dan di atas $50 \%$ dapat dilihat pada Gambar 3 .

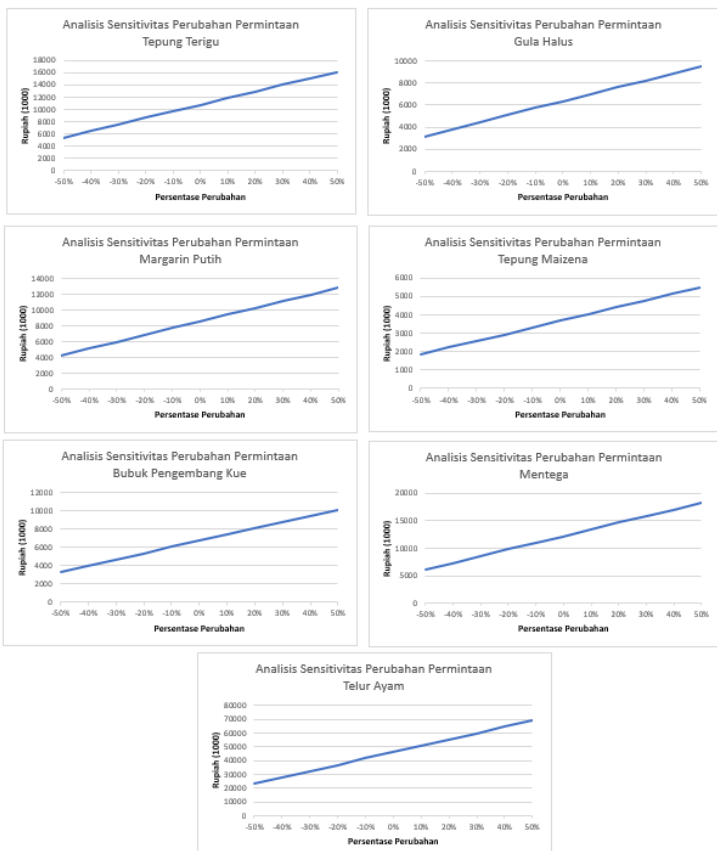

Gambar 3. Analisis sensitivitas terhadap perubahan permintaan

Kenaikan permintaan berbanding lurus dengan kenaikan total biaya bahan baku. 
Kenaikan dan penurunan terlihat sebanding dengan besarnya persentase perubahan permintaan. Model tetap dapat digunakan untuk perubahan permintaan tanpa adanya perubahan variabel lainnya. Selain parameter permintaan, parameter harga memiliki kemungkinan perubahan jika pemasok utama mengajukan kontrak opsi dari usulan kontrak portofolio di tengah kontrak berjalan. Kemungkinan harga dapat naik atau turun dari harga akan mempengaruhi jumlah pembelian yang diajukan oleh perusahaan roti dan kuekue ANDALAS.

Harga mempengaruhi pemilihan pemasok pemesanan. Jika harga di pemasok utama lebih tinggi dibandingkan harga pemasok lain, spot purchase dengan harga lebih rendah akan lebih menguntungkan bagi pihak perusahaan roti dan kue-kue ANDALAS. Analisis sensitivitas dilakukan untuk mengetahui pengaruh dari perubahan harga grosir dan satuan pada pemasok utama.

Analisis sensitivitas terhadap perubahan harga diamati untuk harga grosir berubah, harga satuan berubah, dan keduanya berubah. Penelitian dilakukan untuk masing-masing jenis bahan baku. Analisis dilakukan dengan menggunakan metode enumerasi untuk melihat batasan perubahan optimal sesuai dengan keadaan sesungguhnya.

Pengamatan kenaikan harga grosir dan harga satuan perlu diperhatikan untuk keterkaitan keduanya. Harga grosir pada kenyataannya tidak mungkin lebih tinggi dari harga satuan, begitu pula sebaliknya harga satuan tidak bisa lebih rendah dari harga grosir. Keadaan ini tidak akan diikutsertakan dalam analisis sensitivitas yang dilakukan. Oleh karena itu, batas atas dan batas bawah dari kondisi perubahan yang masih memenuhi syarat agar pembelian seluruhnya dapat dilakukan pada pemasok utama dapat dilihat pada Tabel 13.

Batas bawah dari perubahan harga grosir disesuaikan dengan harga satuan, sedangkan batas atas dari perubahan harga satuan disesuaikan dengan harga grosir. Batas atas dari perubahan harga grosir dimulai dari 0 dikarenakan semakin murah harga grosir, total biaya yang dikeluarkan akan semakin sedikit untuk memenuhi kebutuhan bahan baku. Batas bawah perubahan harga satuan diakhiri dengan harga satuan minimum dari pemasok lain. Ketika harga satuan dan grosir dari pemasok utama lebih tinggi dari harga satuan pemasok lain. Pembelian di pemasok lain akan memiliki total biaya yang lebih rendah. Jika perubahan harga melebihi batas yang didapatkan, model matematis perlu disesuaikan.

Tabel 13. Batas Analisis sensitivitas perubahan harga (dalam Rupiah)

\begin{tabular}{|c|c|c|c|c|}
\hline \multirow[t]{2}{*}{$\begin{array}{c}\text { Jenis Bahan } \\
\text { Baku }\end{array}$} & \multicolumn{2}{|c|}{$\begin{array}{c}\text { Batas } \\
\text { Perubahan } \\
\text { Harga Grosir } \\
\text { Saja }\end{array}$} & \multicolumn{2}{|c|}{$\begin{array}{c}\text { Batas } \\
\text { Perubahan } \\
\text { Harga Satuan } \\
\text { Saja } \\
\end{array}$} \\
\hline & BA & BB & BA & BB \\
\hline Tepung Terigu & 0 & 9500 & 9000 & $\begin{array}{c}1000 \\
0\end{array}$ \\
\hline Tepung Maizena & 0 & $\begin{array}{c}4400 \\
0\end{array}$ & $\begin{array}{c}3575 \\
0\end{array}$ & $\begin{array}{c}4400 \\
0\end{array}$ \\
\hline Baking Powder & 0 & $\begin{array}{c}2550 \\
0\end{array}$ & $\begin{array}{c}2100 \\
0\end{array}$ & $\begin{array}{c}2500 \\
0\end{array}$ \\
\hline Mentega & 0 & $\begin{array}{c}3500 \\
0 \\
\end{array}$ & $\begin{array}{c}3000 \\
0\end{array}$ & $\begin{array}{c}3740 \\
0 \\
\end{array}$ \\
\hline Gula Halus & 0 & 8000 & 6750 & 9000 \\
\hline Margarin Putih & 0 & $\begin{array}{c}2800 \\
0\end{array}$ & $\begin{array}{c}2500 \\
0\end{array}$ & $\begin{array}{c}2600 \\
0\end{array}$ \\
\hline Telur & 0 & $\begin{array}{c}2400 \\
0\end{array}$ & $\begin{array}{c}1900 \\
0\end{array}$ & $\begin{array}{c}2300 \\
0\end{array}$ \\
\hline \multirow{3}{*}{$\begin{array}{c}\text { Jenis Bahan } \\
\text { Baku }\end{array}$} & \multicolumn{4}{|c|}{$\begin{array}{c}\text { Batas Perubahan Harga Grosir } \\
\text { dan Satuan }\end{array}$} \\
\hline & \multicolumn{2}{|c|}{ Harga Grosir } & \multicolumn{2}{|c|}{ Harga Satuan } \\
\hline & BB & BB & BB & BB \\
\hline Tepung Terigu & 9500 & 9500 & 9500 & 9500 \\
\hline Tepung Maizena & $\begin{array}{c}4400 \\
0\end{array}$ & $\begin{array}{c}4400 \\
0\end{array}$ & $\begin{array}{c}4400 \\
0\end{array}$ & $\begin{array}{c}4400 \\
0\end{array}$ \\
\hline Baking Powder & $\begin{array}{c}2550 \\
0\end{array}$ & $\begin{array}{c}2550 \\
0 \\
\end{array}$ & $\begin{array}{c}2550 \\
0\end{array}$ & $\begin{array}{c}2550 \\
0 \\
\end{array}$ \\
\hline Mentega & $\begin{array}{c}3500 \\
0 \\
\end{array}$ & $\begin{array}{c}3500 \\
0 \\
\end{array}$ & $\begin{array}{c}3500 \\
0 \\
\end{array}$ & $\begin{array}{c}3500 \\
0 \\
\end{array}$ \\
\hline Gula Halus & 8000 & 8000 & 8000 & 8000 \\
\hline Margarin Putih & $\begin{array}{c}2800 \\
0\end{array}$ & $\begin{array}{c}2800 \\
0\end{array}$ & $\begin{array}{c}2800 \\
0\end{array}$ & $\begin{array}{c}2800 \\
0\end{array}$ \\
\hline Telur & $\begin{array}{c}2400 \\
0\end{array}$ & $\begin{array}{c}2400 \\
0\end{array}$ & $\begin{array}{c}2400 \\
0\end{array}$ & $\begin{array}{c}2400 \\
0\end{array}$ \\
\hline
\end{tabular}

\section{Kesimpulan}

Berdasarkan penelitian yang telah dilakukan dalam upaya menentukan sistem pengadaan bahan baku utama berbasis kontrak pada perusahaan roti dan kue-kue ANDALAS untuk meminimasi total biaya bahan baku, kontrak pengadaan bahan baku disusun sesuai kebutuhan perusahaan. Pengambilan keputusan dalam kontrak adalah penentuan kuantitas pembelian bahan baku dengan cara optimasi model matematika simplex linear programming. Model dapat menghasilkan penghematan sebesar $6,30 \%$ secara keseluruhan total biaya yang dikeluarkan pada tahun 2017-2019 dengan peningkatan 
keuntungan sebesar $3,4 \%$ dari pencapaian keuntungan awal. Hasil penerapan model menunjukkan bahwa pembelian bahan baku utama secara keseluruhan akan dilakukan pada supplier utama dengan total pembelian $1175 \mathrm{~kg}$ tepung terigu, 103 pax tepung maizena, 319 pax baking powder, 203 pax mentega, $940 \mathrm{~kg}$ gula halus, $330 \mathrm{~kg}$ margarin putih, dan 2415 kilogram telur ayam. Penghematan secara berurutan untuk tepung terigu, tepung maizena, baking powder, mentega, gula halus, margarin putih, dan telur ayam secara berurutan adalah $4,27 \%, \quad 16,30 \%, \quad 11,51 \%, \quad 7,13 \%, \quad 5,92 \%$, $12,87 \%$, dan $4,40 \%$.

\section{Daftar Pustaka}

Chopra, S., \& Meindl, P. (2010). Supply Chain Management: Strategy, Planning, and Operation, 4th edition, Pearson Education.
KBBI, 2020. Kamus Besar Bahasa Indonesia (KBBI). [Online] Available at: http://kbbi.web.id, [Diakses 7 Februari 2020].

LKPP, 2020. Lembaga Kebijakan Pengadaan Barang/Jasa Pemerintah (LKPP). [Online] Available at: http://www.lkpp.go.id/v3/, [Diakses 19 Juli 2020].

Martinez-de-Albeniz, V., \& Simchi-Levi, D. (2009). A Portfolio Approach to Procurement Contracts. Production and Operation Management, 14(1), 90-114. DOI: 10. 1111/j. 1937-5956.2005.tb00012.x

Simchi-Levi, D., Kaminsky, P., Simchi-Levi, E. (2008). Designing and Managing Supply Chain: Concepts, Strategies, and Case Studies, 3rd Edition. Boston: Mc-Graw Hill.

Sitompul, C. (2019). Optimasi Rantai Pasok: Formulasi dan Solusi. Deepublish Publisher. 